\title{
Peripheral Target Regulation of Dendritic Geometry in the Rat Superior Cervical Ganglion
}

\author{
James T. Voyvodic \\ Department of Anatomy and Neurobiology, Washington University School of Medicine, St. Louis, Missouri 63110
}

Dendritic arborizations of neurons in the adult rat superior cervical ganglion were measured in control ganglia and in ganglia innervating peripheral targets that were relatively larger or smaller than normal. The relative size of the target-the submandibular gland in these experiments-was manipulated during development by changing the ratio between the amount of target tissue and the number of innervating ganglion cells. Thus, ligating the submandibular salivary duct reduced the size of the gland, whereas partially denervating the gland produced a relatively larger target by making a smaller number of ganglion cells innervate a gland of normal size. Neurons innervating targets that were smaller than normal had significantly smaller dendritic arborizations and cell bodies than control cells. Conversely, neurons projecting to relatively larger than normal targets had larger dendritic arborizations and cell bodies, and more primary dendritic branches. Such cells were also innervated by a larger than normal number of preganglionic inputs. A similar change in dendritic geometry was observed when relative target size was increased after cutting the cervical sympathetic trunk, showing that target regulation of dendritic geometry is not dependent on ganglion cell activity or the presence of presynaptic innervation.

Dendrites in the superior cervical ganglion normally grow in parallel with body size throughout life (Purves et al., 1986a; Voyvodic, 1987a). The present results imply that an important aspect of dendritic growth is an ongoing responsiveness of ganglion cells to feedback signals arising from the peripheral targets they innervate.

The size and shape of a neuron's dendritic arborization affect the manner in which neurons process synaptic information. Thus, both the passive spread of synaptic potentials (Rall, 1977; LevTov et al., 1983) and the number of axons that innervate each nerve cell (Purves and Hume, 1981; Purves and Lichtman, 1985a) are critically influenced by the geometry of the dendritic arborization. Despite the importance of these issues, there is little information about how the size and form of dendrites are regulated.

\footnotetext{
Received July 14, 1988; revised Oct. 24, 1988; accepted Nov. 3, 1988.

This work was supported hy a National Science Foundation Graduate Fellowship to J.V. and by grants from the National Institutes of Health (NS 11699 and 18629) to Dale Purves. I thank Dr. Purves for support and guidance throughout this study, and S. Pomeroy, A-S. LaMantia, and W. Snider for useful comments on the manuscript. I also thank P. Newton and D. Dill for their excellent technical assistance.

Correspondence should be addressed to the author at his present address: Department of Biology, Medawar Building, University College London, Gower Street, London WC1E 6BT, UK.

Copyright (C) 1989 Society for Neuroscience $0270-6474 / 89 / 061997-14 \$ 02.00 / 0$
}

The present work focuses on the regulation of dendrites in a simple part of the rat nervous system, the superior cervical ganglion. The experiments reported here test the hypothesis that the geometry of dendrites in the superior cervical ganglion is regulated by the relative size of the peripheral axonal target. This hypothesis is based upon 3 observations. First, throughout normal development there is a strong correlation between ganglion cell dendritic geometry and animal size (Voyvodic, 1987a). Second, a similar correlation is observed when species of different size are compared; the ganglionic ncurons of larger specics have more complex dendritic arborizations than homologous neurons in smaller species (Purves et al., 1986a). Third, ganglion cell dendrites are not much affected by removal of preganglionic innervation, either during development (Smolen and BeastonWimmer, 1986; Voyvodic, 1987a) or in adult animals (McLachlan, 1974).

To test the role of targets in regulating dendritic geometry, the relative size of a postganglionic target, the submandibular salivary gland, was altered by changing the ratio between the amount of target tissue and the number of innervating ganglion cells. In this way, the number of target cells available to each neuron could be either decreased or increased. Ganglion cell dendritic geometry was subsequently evaluated by intracellular injection of HRP.

The outcome of these experiments shows that ganglion cells innervating relatively larger targets elaborate more complex dendritic arborizations than normal, whereas cells innervating relatively smaller targets have simpler geometries. This regulation is independent of neuronal activity since similar results were obtained in the absence of preganglionic innervation. These observations therefore indicate that the growth of sympathetic ganglion cell dendrites is regulated, at least in part, by retrograde signals derived from the peripheral target. Some of these results have been briefly reported (Voyvodic, 1987b).

\section{Materials and Methods}

In the rat, the submandibular gland is one of the largest targets of the superior cervical ganglion, being innervated by approximately $16 \%$ of the neurons in the ganglion (unpublished observations). This target was chosen because of its convenient location and the ease with which it can be manipulated. The size of the submandibular gland was experimentally altered in male albino rats (Holtzmann strain) using 2 different surgical procedurcs. In onc scrics of experiments, the size of the target was reduced by ligating the submandibular salivary duct in young animals, thereby preventing normal growth of the gland (Tamarin, 1966; Womble and Roper, 1987). In the second series of experiments, a relatively larger than normal target was produced by partially denervating the salivary gland at birth. Since ganglion cells axotomized early in life do not survive (Hendry and Campbell, 1976; Wright et al., 1983), partial denervation of the submandibular gland at birth increases the ratio between the size of the target and the number of superior cervical gan- 


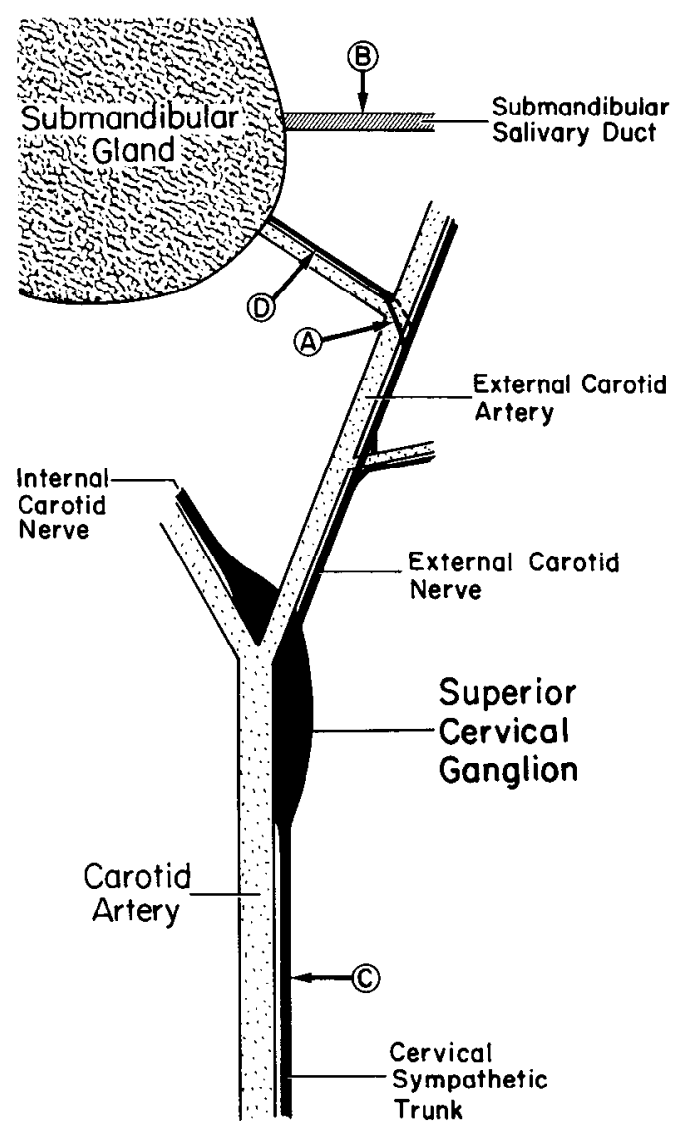

Figure 1. Innervation of the submandibular gland by the superior cervical ganglion. In one experimental group, the submandibular gland was partially denervated by cutting a branch of the postganglionic nerve to the gland where it leaves the trunk of the external carotid nerve (arrow $A)$. In a second group, the size of the gland was reduced by ligating the submandibular duct with surgical suture (arrow $B$ ). In a third group, preganglionic innervation to the superior cervical ganglion was removed by ligating and transecting the cervical sympathetic trunk several millimeters caudal to the ganglion (arrow $C$ ). In a fourth group, preganglionic denervation at $C$ was combined with partial denervation of the gland at $A$. For every animal, a portion of the postganglionic nerve (arrow $D$ ), approximately midway between the submandibular gland and the external carotid nerve trunk, was removed for electron microscopy at the time the animal was killed.

glion cells that innervate it. In both of these surgical procedures the relative size of the target was effectively changed without injury to the remaining sympathetic neurons. Dendritic geometry was evaluated in adult animals (4-6 months old).

Salivary duct ligation. A smaller than normal target was created by ligating the submandibular duct. Preliminary experiments showed that when this procedure was carried out at birth, ganglion cell death caused a commensurate reduction of the number of superior cervical ganglion neurons that innervated the gland; this adjustment is consistent with present understanding of the target-dependent mechanisms of neuronal survival (reviewed by Oppenheim, 1981; Purves and Lichtman, 1985b). Therefore, to reduce the size of the gland without changing the number of ganglion cells, the salivary duct was ligated in animals 4 weeks of age. This age was chosen because it is after the period of normally occurring ganglion cell death (Hendry and Campbell, 1976; Wright et al., 1983). To ligate the duct, animals were anesthetized with chloral hydrate $(0.35 \mathrm{gm} / \mathrm{kg})$ and the right submandibular duct was exposed and carefully separated from the surrounding blood vessels and parasympathetic nerve branches. The duct was then ligated with a 6-0 silk suture midway between the gland and the digastric muscle (Fig. 1). After closing the wound, the animals were returned to the litter. In shamoperated control animals, the same procedure was followed except that the wound was closed immediately after exposing the duct.
Partial denervation of target. Newborn rats (1-3 d old) were anesthetized by cooling, and the right submandibular gland was exposed via a midline incision in the neck. The postganglionic sympathetic nerve that carries the axons from the superior cervical ganglion to the gland was identified where it leaves the external carotid nerve (Fig. 1). The nerve to the gland typically bifurcates as it goes around the glandular branch of the external maxillary artery, fusing again before it enters the gland. To partially denervate the target, the larger of the 2 branches around the artery was cut. Care was taken to not disturb the other branch. The wound was closed and the animals returned to the litter. In shamoperated animals, the postglanglionic nerve was exposed but not cut.

In 4 additional rats, the preganglionic cervical sympathetic trunk was ligated and cut (for details, see Voyvodic, 1987a) at the same time that the postganglionic nerve to the submandibular gland was partially transected as described above. In 3 other animals, the preganglionic nerve was cut without disturbing the target's postganglionic connections. These manipulations were performed to determine whether target-induced changes in dendrites might also be influenced by the presence of presynaptic innervation to the ganglion cells.

Identification of neurons projecting to the submandibular gland. Rats that had been subjected to these surgical procedures were again anesthetized with chloral hydrate $(0.35 \mathrm{gm} / \mathrm{kg})$ at $4-6$ months of age, and the right submandibular gland was labeled with the fluorescent marker 1,1'-dioctadecyl-3,3,3',3'-tetramethylindocarbocyanine perchlorate (DiI; Molecular Probes; Honig and Hume, 1986). The dye was applied by gently separating the lobes of the gland and inserting a few crystals into this space together with a drop of $25 \%$ DMSO to aid in dye uptake. The wound was closed, and the animals were returned to their cages for 7-14 $\mathrm{d}$ to allow time for the dye to be retrogradely transported to the superior cervical ganglion. This technique specifically labels ganglion cells that project to the submandibular gland (Fig. 2).

Evaluation of dendritic geometry. Rats were killed by cardiac perfusion with Ringer's solution (Johnson and Purves, 1981) after being anesthetized with sodium pentobarbitol $(50 \mathrm{mg} / \mathrm{kg})$. The right superior cervical ganglion was dissected free and pinned out in a Sylgard-coated culture dish. The ganglionic capsule was gently removed to facilitate visualization and impalement of the neurons. The dish was then placed on the stage of a standard epifluorescence microscope (Leitz Orthoplan) equipped with a $150 \mathrm{~W}$ xenon lamp. A continuous flow of oxygenated Ringer's was adjusted so that the fluid level just covered the ganglion; ganglion cells were then visualized using a long working distance $32 \times$ objective (Leitz; $4.5 \mathrm{~mm}, \mathrm{NA}=0.4$ ). Neurons innervating the submandibular gland were identified by the presence of $\mathrm{Di}-\mathrm{I}$, which was visualized using filters for rhodamine wavelengths (Leitz N2 cube) (Fig. 3A).

In order to avoid introducing a bias in choosing which neurons to inject, the following cell selection protocol was adopted. Starting at the caudal end of the ganglion, one cell was injected per microscope field; the field was moved approximately $800 \mu \mathrm{m}$ rostrally after each cell had been labeled. Within each field of view $\left(0.25 \mathrm{~mm}^{2}\right)$, the Di-I-labeled cell closest to the upper surface of the ganglion was always selected. This protocol ensured that comparable cell populations would be obtained from each animal (and also took advantage of the fact that the most superficial neurons are the easiest to impale). Neurons were impaled with microelectrodes pulled from triangular glass (Glass Co. of America) containing a mixture of 5\% HRP (Sigma type VI) and $0.1 \%$ 5(6)-carboxyfluorescein; electrodes had resistances of 120-160 MR. Using a broad-band fluorescein filter set (Leitz H3 cube), both the Di-Ifilled neurons and the carboxyfluorescein-filled electrode could be seen simultaneously, thus permitting accurate placement of the microelectrode tip (Fig. $3 B$ ). The amount of time that the electrode and ganglion were illuminated with light of the exciting wavelength was kept to a minimum because prolonged excitation of the carboxyfluorescein appeared to inactivate the HRP.

A satisfactory impalement was characterized by a stable resting potential and an overshooting action potential in response to depolarizing current. A small amount of carboxyfluorescein was injected iontophoretically using hyperpolarizing current $(1 \mathrm{nA}, 5 \mathrm{~Hz}, 50 \mathrm{msec}$ pulses for $10 \mathrm{sec}$ ) to verify by direct visualization that the correct neuron had been impaled (Fig. 3C). HRP was then injected by passing depolarizing current for $6 \mathrm{~min}(5 \mathrm{nA}, 5 \mathrm{~Hz}, 50 \mathrm{msec}$ square pulses). After 8-12 neurons had been labeled in this way, the ganglion was fixed overnight $(1.25 \%$ glutaraldehyde, $0.5 \%$ paraformaldehyde) before developing the HRP reaction product by the method of Hanker et al. (1977). The ganglion was subsequently dehydrated through a series of graded ethanol solutions, cleared in methyl benzoate, and mounted whole on a microscope slide. The dendritic arborizations of HRP-filled cells were traced using 

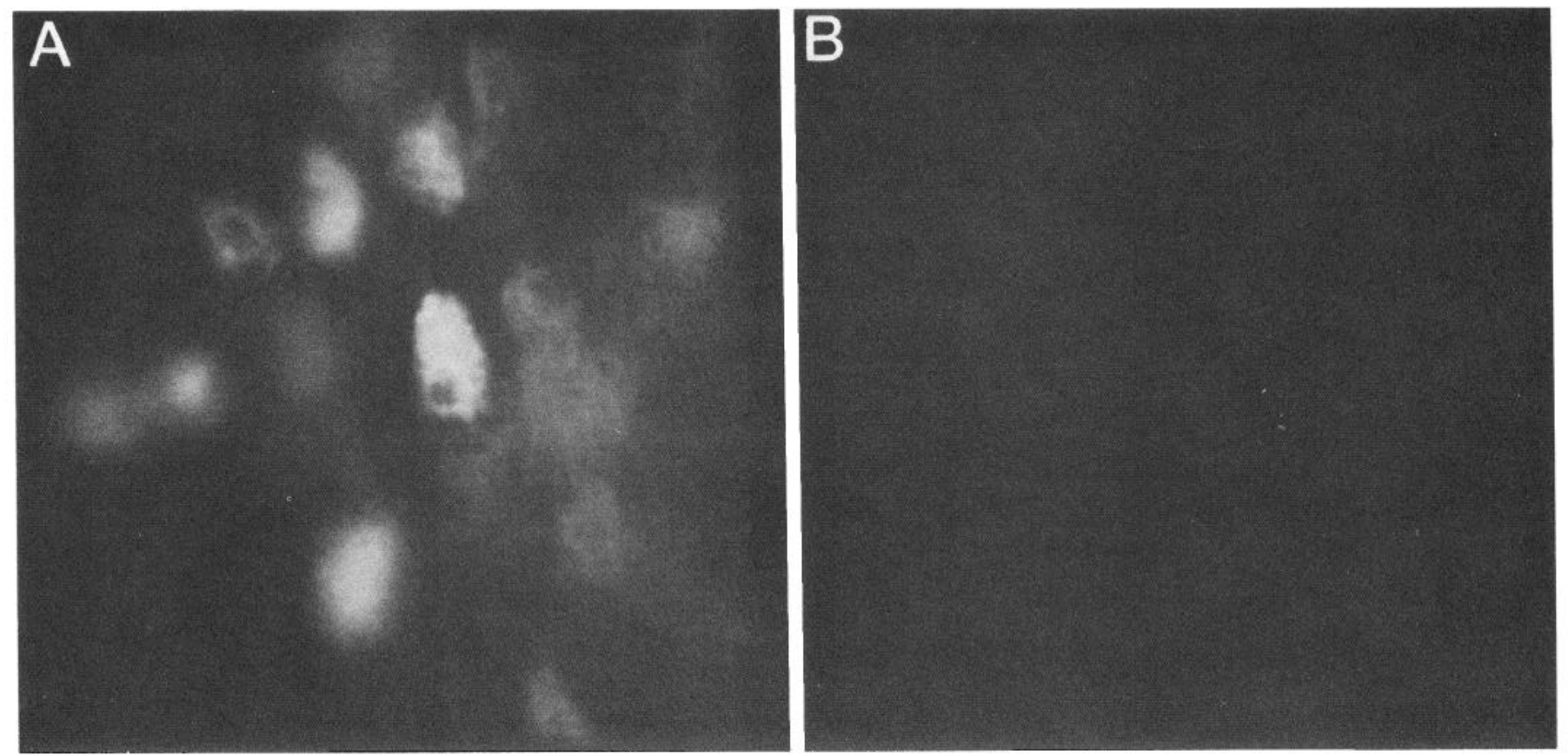

Figure 2. Specific retrograde labeling of superior cervical ganglion cells from the submandibular gland. $A$, By $7 \mathrm{~d}$ after applying crystals of Di-I to the submandibular gland, many neurons in the ganglion exhibited bright fluorescence. $B$, When Di-I was applied to the gland after first cutting the postganglionic sympathetic nerve near the submandibular gland (see arrow D in Fig. 1), fewer than $2 \%$ of the normal number of labeled cells were seen in the superior cervical ganglion; the label is therefore specifically transported by postganglionic axons.

a drawing tube, and dendritic lengths measured using a digitizing tablet (see Voyvodic, 1987a, for details).

Determination of the number of ganglion cells innervating the gland. For every experimental animal, the total number of axons in the postganglionic sympathetic nerve innervating the right submandibular gland was counted. To do this, a portion of the postganglionic nerve near the gland (see Fig. 1) was removed and fixed for electron microscopy by submersion for at least $48 \mathrm{hr}$ in $2 \%$ paraformaldehyde, $2 \%$ glutaraldehyde, and $4 \%$ sucrose in $0.1 \mathrm{~m}$ phosphate buffer. Nerves were postfixed in $1 \%$ osmium, dehydrated in a series of ethanol solutions followed by a series of propylene glycol solutions, and embedded in Araldite. Thin sections were cut and placed on Formvar-coated slot grids, stained with uranyl acetate and lead citrate, and viewed with a JEOL electron microscope. Cross sections of the nerve were photographed at $2000 \times$ primary magnification, and the total number of axons was counted in a photomontage of the whole nerve.

To determine the relationship between the number of axons in the postganglionic sympathetic nerve and the number of ganglion cells innervating the gland, the number of axons was directly compared with the number of cells in the ganglion retrogradely labeled after soaking the nerve in a solution of 50\% HRP and 2\% lysolecithin (Purves et al., 1986a). This was done for 3 rats: 1 control, 1 with partially denervated gland, and 1 with ligated salivary duct. For these adult animals the number of axons agreed with the number of retrogradely labeled cells to within $5 \%$. Since transecting the postganglionic nerve eliminates almost all retrograde labeling of Di-I from the gland to the ganglion (Fig. 2 ), virtually all the ganglion cell axons innervating the gland are contained in this nerve. Based on these observations, therefore, the number of axons in the nerve was used in this study as a reasonably accurate measure of the number of superior cervical ganglion cells innervating the gland.

Measurement of gland innervation by catecholamine histofluorescence. Three animals in each of the 3 main experimental groups (controls, relatively enlarged target size, and relatively reduced target size) were used to evaluate the effect of the surgical procedures on the innervation of the target itself. These animals were killed at 4-6 months of age, and both the left and right submandibular glands were removed, weighed, and rapidly frozen in liquid nitrogen-cooled isopentane. A portion of the postganglionic nerve to the right gland was removed and processed for electron microscopy as described above. Sections of the frozen glands
$16 \mu \mathrm{m}$ thick were cut on a cryostat, placed on microscope slides, and dipped for $10 \mathrm{sec}$ in a $1 \%$ glyoxylic acid solution (Tervo et al., 1978). Sections were air-dried and then placed in a $95^{\circ} \mathrm{C}$ oven for $10 \mathrm{~min}$. Sympathetic axons were visualized by catecholamine fluorescence when sections were illuminated with violet light (Leitz D cube).

The density of sympathetic innervation in the gland was measured using a low-light level video camera (GE SIT model 4TE) and an image processor (Recognition Concepts Inc. Trapix 5500) to digitize the fluorescent images. An image-processing algorithm written in the IMAGR programming language (Voyvodic, 1986, and unpublished observations) was used to determine the density of fluorescent nerve fibers. This algorithm involves first normalizing the overall intensity level using a local background subtraction convolution and then quantifying the fraction of the image at intensity levels $10 \%$ above baseline (Fig. 4). This procedure gives reproducible measurements $(5 \%$ deviation on multiple trials) and is essentially independent of variations in overall fluorescence intensity or positional nonlinearities in the optical system. To allow for histochemical variability among different animals, measurements are expressed as the density of innervation in the right (experimental) gland divided by the density of innervation in the left (control) gland.

Determination of preganglionic convergence. The number of preganglionic axons innervating individual superior cervical ganglion neurons that project to the submandibular gland was determined electrophysiologically for 3 control animals and for 5 animals in which target size was increased by partially denervating the gland. This technique and its limitations are described in detail elsewhere (Njå and Purves, 1977). Briefly, at 7 months of age the rats were anesthetized and perfused with Ringer's solution; the right superior cervical ganglion was dissected free in continuity with the sympathetic trunk and ventral roots, from the level of the eighth cervical to the seventh thoracic segment of the spinal cord. The 8 ventral roots were drawn into separate suction electrodes for stimulation of preganglionic axons. A suction electrode was also applied to one of the ganglion's postganglionic nerves (the internal carotid) to monitor the integrity of the preparation. Ganglion cells innervating the submandibular gland were identified by Di-I labeling as described above and impaled with intracellular electrodes containing $2 \mathrm{M}$ $\mathrm{KCl}$ and $0.1 \% 5(6)$-carboxyfluorescein (tip resistances, 20-30 M 2 ). The number and size of preganglionic inputs was determined for each ventral root by measuring steps in the intracellular voltage response while gradually increasing the stimulation intensity (Njå and Purves, 1977). 


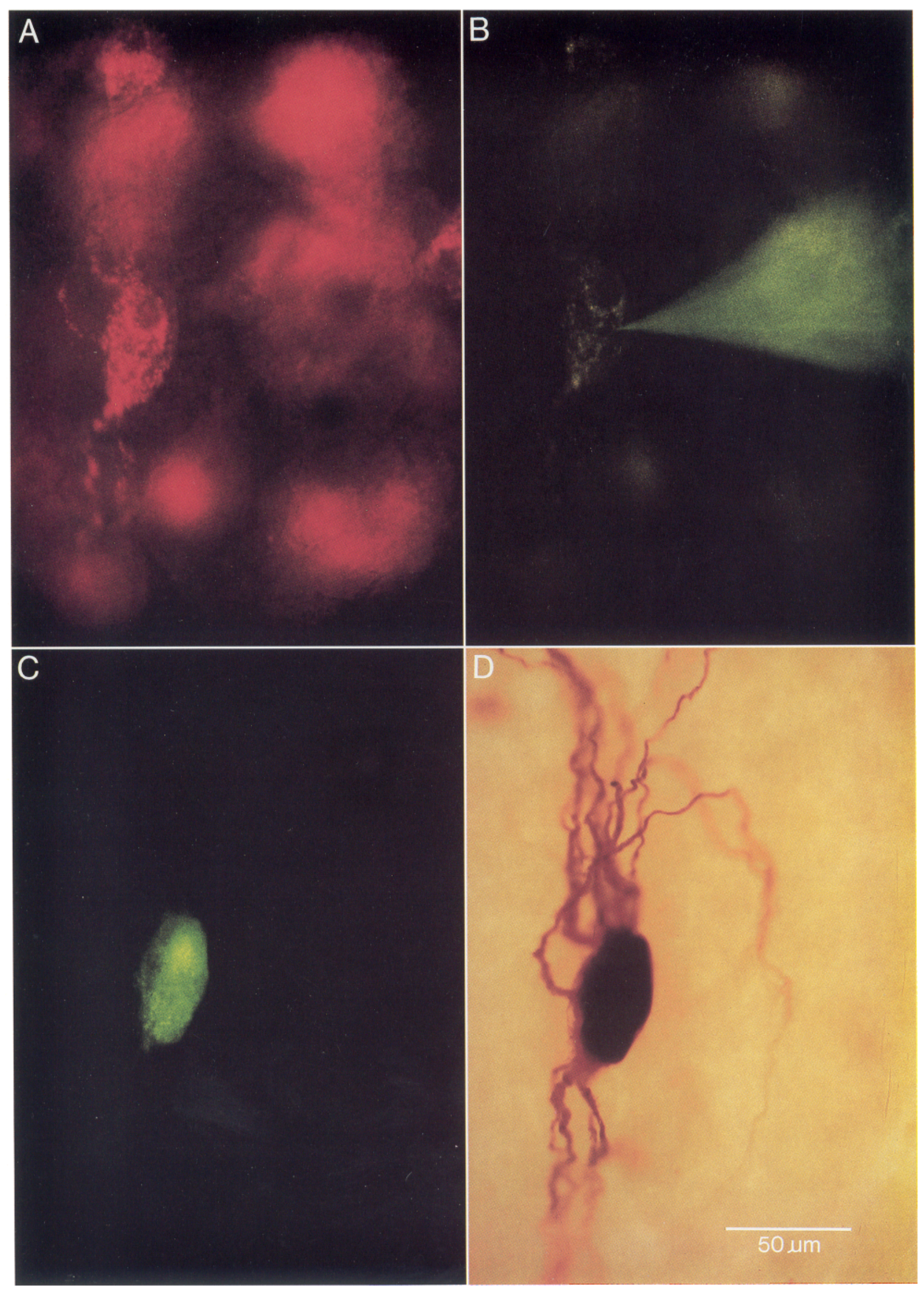



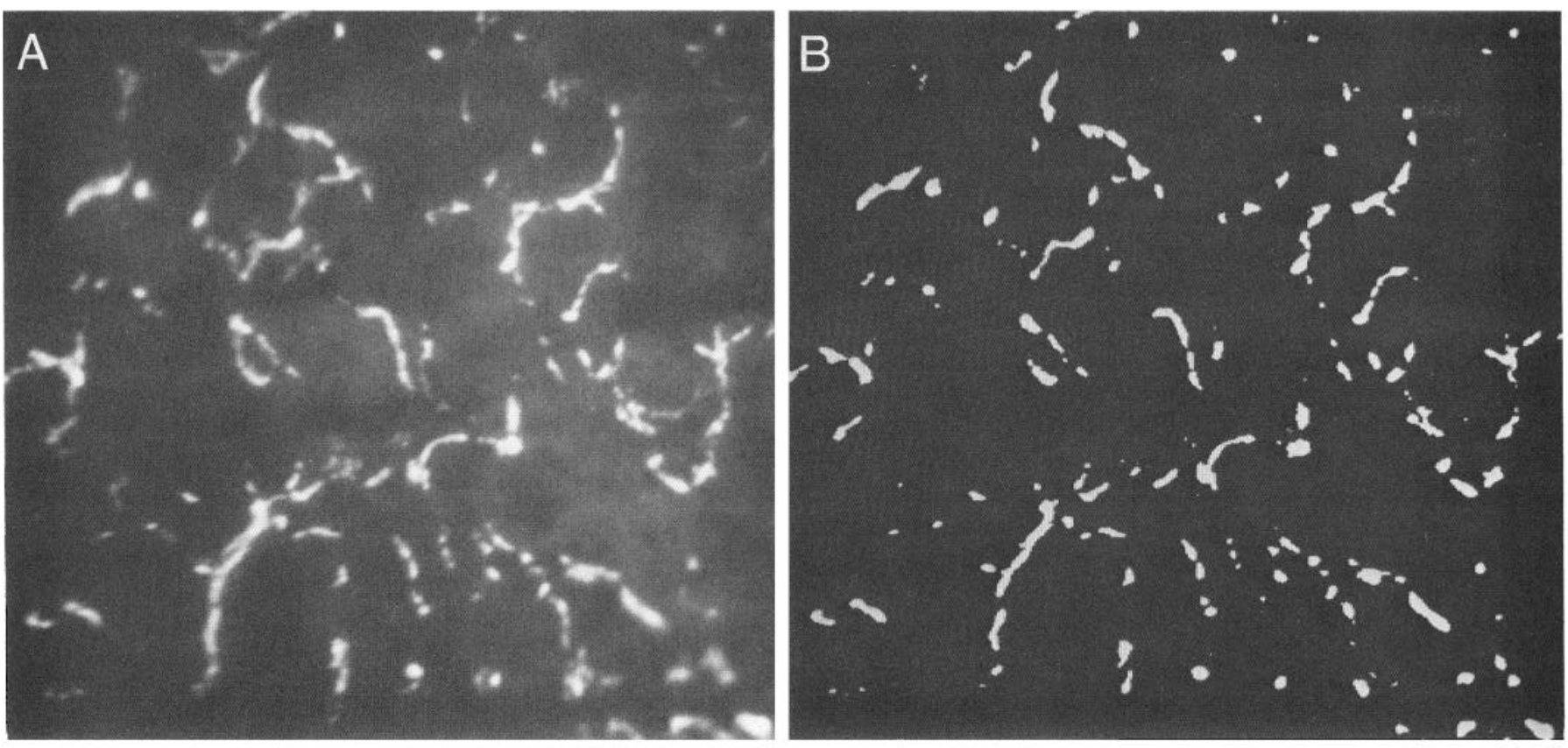

Figure 4. Measuring the density of sympathetic innervation as shown by catecholamine histofluorescence. $A$, Sympathetic axons in the submandibular gland were labeled by glyoxilic acid histochemistry, and images of fluorescent fibers were viewed with a low-light-level video camera and then digitized and averaged using an image processor. $B$, Digitized images were further processed by subtracting out low spatial frequency components of the image and then setting a cutoff threshold intensity level. The resultant image indicates those portions of the original digitized image that contained in-focus fluorescence; out-of-focus label was largely eliminated by the spatial frequency filter. The amount of fluorescence was then quantified as the fraction of the image that is non-zero. In this example, $3.72 \%$ of the image was labeled.

\section{Results}

Normal geometry of superior cervical ganglion cells projecting to the submandibular gland

A total of 59 superior cervical ganglion neurons that innervated the submandibular gland in 12 control rats was intracellularly labeled with HRP. These neurons had an average total dendritic length of $3527 \pm 200$ (SEM) $\mu \mathrm{m}$, with $6.3 \pm 0.4$ primary dendrites. A primary dendrite was defined as a process other than the axon, arising from the cell soma and extending at least one cell body diameter in length. The average cell body diameter of these neurons was $38.4 \pm 0.8 \mu \mathrm{m}$. Ganglion cells that did not contain the Di-I label, and therefore innervated targets other than the submandibular gland, had an average total dendritic length of $2198 \pm 317 \mu \mathrm{m}(n=10)$ microns with $5.8 \pm 0.6$ primary dendrites and cell soma size of $33.6 \pm 1.5 \mu \mathrm{m}$. The values for non-gland projecting neurons are similar to previous reports of much larger numbers of superior cervical ganglion cells injected without regard to their target specificity (Purves and Lichtman, 1985a; Voyvodic, 1987a). Thus, neurons that projected to the submandibular gland appeared to be somewhat larger, on average, than ganglion cells innervating other targets.

\section{Experimental modification of relative target size}

Ligating the salivary duct at 4 weeks of age resulted in a significantly smaller than normal submandibular gland in the adult. The weights of the right (experimental) submandibular glands in duct ligated animals $(n=9)$ were, on average, only $20 \%$ $( \pm 1.0 \% \mathrm{SEM})$ that of glands in control animals. The decrease in gland size is due primarily to atrophy of the secretory cells of the salivary acini (Tamarin, 1966). No change was observed in the contralateral gland. These observations are consistent with previous studies of the effect of submandibular duct ligation in the rat (op cit.). In contrast to the large reduction in target size, duct ligation at 4 weeks of age had little effect on the number of superior cervical ganglion neurons innervating the submandibular gland. The number of neurons projecting to atrophic glands was not significantly different from control values (Table 1).

Partial denervation of the submandibular gland produced an opposite change. Rats in which the right gland was partially denervated at birth showed no change in the mass of the submandibular gland but a significant reduction in the mean number of ganglion cells projecting to it (Table 1). Since the branching pattern of the postganglionic nerve can be quite different in

Figure 3. Intracellular labeling of superior cervical ganglion neurons innervating the submandibular gland. All 4 panels show that the same region of a rat SCG. In panels $A-C$, the cells are still alive in the isolated ganglion in physiological Ringer's solution; panel $D$ shows the same cell after the ganglion has been fixed, dehydrated, cleared, and whole-mounted. $A$, Using rhodamine filters many cells are seen to be retrogradely labeled with $\mathrm{Di}-\mathrm{I}$ transported from the submandibular gland. $B$. One labeled cell is selected and impaled with an intracellular micropipette using fluorescein optics. $C$, The marker 5,6-carboxyfluorescein is injected to verify that the cell selected has actually been impaled, $D$, HRP is then injected and later reacted to reveal the entire dendritic arbor. 

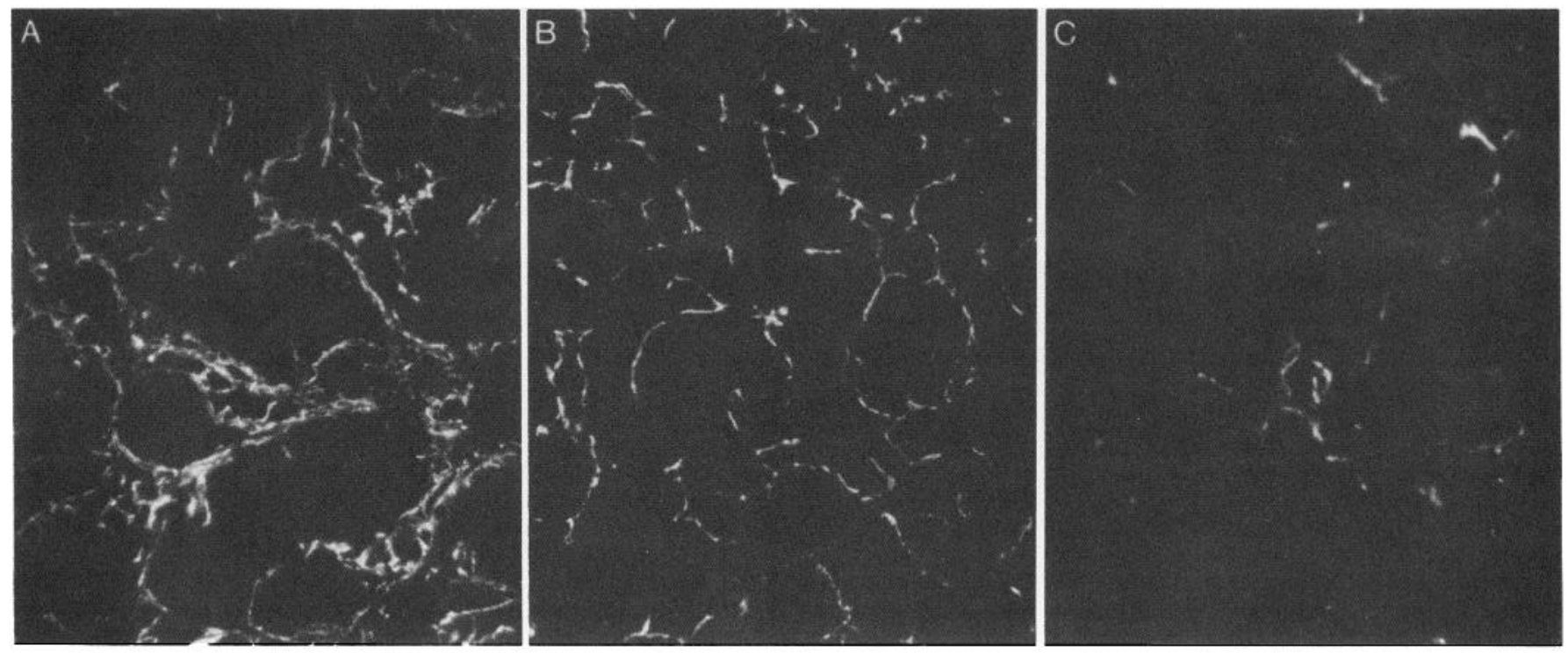

Figure 5. Sympathetic innervation of the submandibular gland following surgical manipulations to alter relative target size. Representative photomicrographs of histological sections reacted for catecholamine-induced fluorescence of sympathetic axons are shown for a duct-ligated gland $(A)$, a control gland $(B)$, and a partially denervated gland $(C)$. Quantification of these images (see Fig. 4$)$ gave values of $10.6 \%(A), 6.9 \%(B)$, and $2.0 \%(C)$, which are close to the means measured for the 3 experimental conditions (Table 1$)$.

different rats, the number of neurons axotomized at birth varied significantly from animal to animal. As a result, there was considerable variability in the number of surviving superior cervical ganglion neurons among the partially denervated animals. In some cases, the number of ganglion cells was reduced by as much as $95 \%$; in animals in which the severed nerve branch was small, however, neuronal number was nearly normal. Because of this variability, a criterion for successful partial denervation was arbitrarily defined as a reduction in the number of axons in the postganglionic nerve to at least $25 \%$ below the average control number of 3800 . On this basis, 2 of 11 rats were excluded from the partially denervated group since in those cases the surgery was ineffective in significantly reducing the number of ganglion cells. (However, these 2 rats are included in the analysis of individual animals shown in Fig. 9.)

A quantitative measure of the relative size of the peripheral target was calculated for the 2 surgical procedures by dividing the mass of the submandibular gland by the number of ganglion cells that ultimately projected to it. On average, duct ligation decreased the ratio of gland size to ganglion cell number to $24 \%$ of the value for control rats, while successful partial denervation increased this ratio to an average of $747 \%$ of control (Table 1). In summary, therefore, duct ligation significantly reduces, and partial denervation significantly increases, the size of the peripheral target relative to the number of neurons available to innervate it.

\section{Effect of changing relative target size on innervation of the salivary gland}

The effect of these surgical procedures on sympathetic innervation within the peripheral target was assessed by measuring the density of catecholamine-containing axons in the subman-

Table 1. Effect of surgical procedures on innervation of the submandibular gland

\begin{tabular}{lccc} 
Parameter & Control & $\begin{array}{l}\text { Ligated } \\
\text { salivary } \\
\text { duct }\end{array}$ & $\begin{array}{l}\text { Partially } \\
\text { denervated } \\
\text { gland }\end{array}$ \\
\hline $\begin{array}{l}\text { No. of animals } \\
\text { Body weight (gm) }\end{array}$ & 12 & 9 & 9 \\
Gland weight (gm) & $421.1 \pm 14$ & $393 \pm 14$ & $407 \pm 13$ \\
$\quad$ Right & $356 \pm 14$ & $72^{a} \pm 5.6$ & $343 \pm 9.9$ \\
$\quad$ Left & $362 \pm 14$ & $361 \pm 21$ & $367 \pm 18$ \\
No. of axons innervating right gland & $3807 \pm 123$ & $3413 \pm 266$ & $986^{a} \pm 281$ \\
Relative target size ( $\mu$ g/axon) & $95.9 \pm 5.9$ & $21.8^{a} \pm 2.1$ & $716^{a} \pm 191$ \\
Density of innervation (right/left) & $1.00 \pm 0.02$ & $1.41^{a} \pm 0.030$ & $0.37^{a} \pm 0.01$ \\
Innervation per axon (\% control) & $100 \pm 6$ & $31^{a} \pm 3$ & $280^{a} \pm 30$
\end{tabular}

Relative target size was calculated as the weight of the right submandibular gland divided by the number of innervating axons. Density of target innervation was determined by measuring amount of catecholamine induced fluorescence (see Materials and Methods). Innervation per axon was calculated by multiplying the density of innervation times the weight of the right gland, then dividing by the number of axons innervating that gland. Numbers are given \pm SEM.

${ }^{a}$ Values significantly different from controls ( $p<0.005$ by Student's $t$ test). 


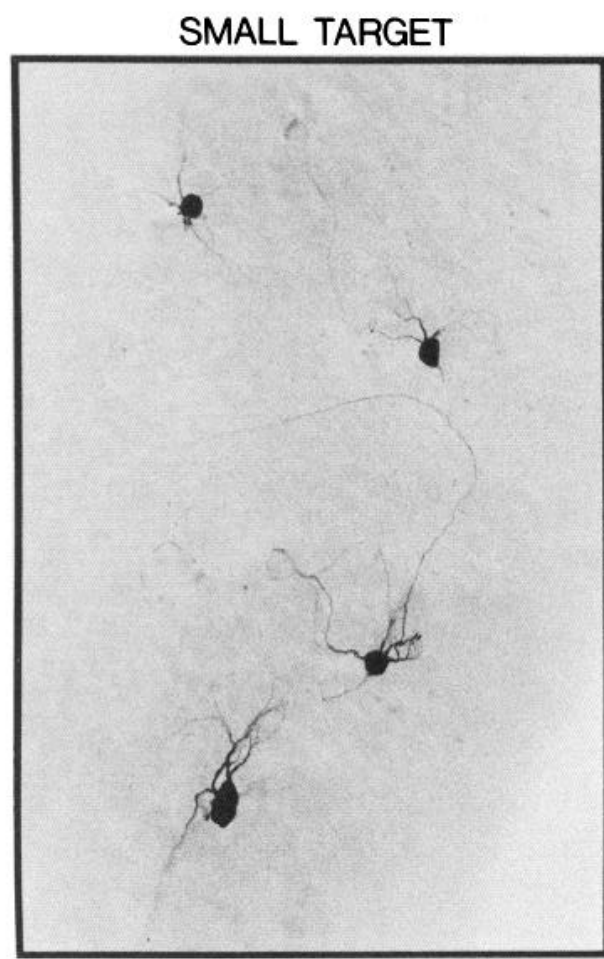

(Ligated Salivary Duct)

NORMAL TARGET LARGE TARGET

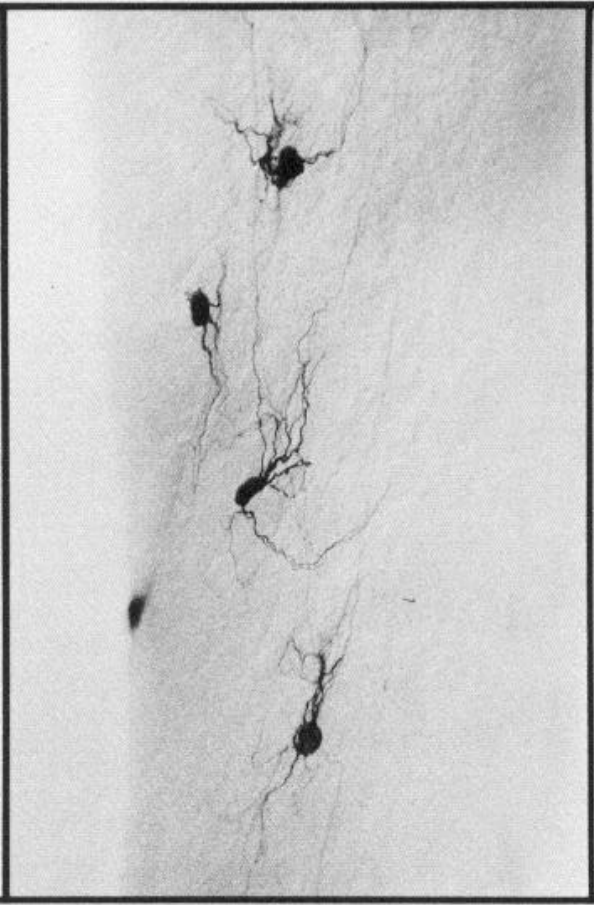

(Control)

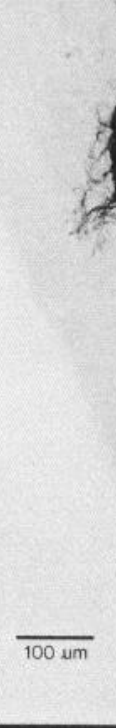

(Partially Denervated Gland)

Figure 6. Influence of target size on dendritic geometry in the superior cervical ganglion. All 3 panels show HRP-labeled neurons in representative whole-mounted ganglia from 4-month-old rats. All 4 neurons in each panel innervated the submandibular gland, as determined by retrograde Di-I labeling (Fig. 3). Left, Neurons in a ganglion innervating a relatively small target in an animal in which the submandibular duct was ligated at 4 weeks of age. Center, Neurons in a ganglion from a control animal. Right, Neurons projecting to a relatively large target in an animal in which the submandibular gland was partially denervated at birth. Scale bar applies to all 3 panels.

dibular gland (Fig. 5). Compared with controls, ligating the salivary duct resulted in a $41 \%$ increase in the staining density of sympathetic fibers. Conversely, partially denervating the gland resulted in a $63 \%$ decrease in axonal density. To estimate the total size of the terminal arborization for individual axons under each test condition, the average density of innervation per gland was multiplied by the size of the gland per innervating axon (Table 1). This calculation indicates that decreasing relative target size by duct ligation produced a $69 \%$ decrease in the average size of individual axonal arborizations in the gland, whereas increasing relative target size by partial denervation resulted, on average, in axonal arborizations $180 \%$ larger than normal. The fact that axons did not sprout to innervate the entire gland after partial denervation is consistent with similar observations on partial denervation of skeletal muscle (Brown et al., 1976; Thompson and Jansen, 1977; Betz et al., 1980; Fladby and Jansen, 1987).

\section{Effect of peripheral target size on neuronal geometry}

Approximately 50 superior cervical ganglion neurons that projected to the submandibular gland were intracellularly labeled with HRP in animals with ligated salivary ducts, partially denervated salivary glands, and in control animals (Table 2). Rats in each of these 3 groups were matched for age and weight. Figure 6 shows representative ganglia from the 3 groups to illustrate the main result obtained. Reducing target size by duct ligation resulted in smaller cell bodies and smaller dendritic arborizations compared with control animals. Thus, average soma diameter was reduced by $21 \%$, and average dendritic length was reduced by $36 \%$ following duct ligation. In contrast, increasing relative target size by partial denervation resulted in larger cell bodies and larger dendritic arborizations. Partial denervation increased mean soma diameter by $16 \%$ and dendritic length by $34 \%$. Frequency histograms comparing morphometric parameters for neurons in each of the 3 test groups are shown in Figure 7.

Increasing relative target size by partial denervation also resulted in ganglion cells with more than the usual number of primary dendrites. In these animals, the average number of dendrites was $12.8 \pm 0.7$ (SEM), whereas the control value was $6.3 \pm 0.4$. Several cells possessed more than 20 primary dendrites (Fig. 7), far more than the maximum of 15 seen among control cells (see also Purves and Lichtman 1985a; Voyvodic, 1987a; Snider, 1988). Interestingly, however, the number of primary dendrites did not vary symmetrically with target size. When peripheral target size was reduced by ligating the submandibular duct, there was no change in the number of primary dendrites. For those animals the mean number of primary dendrites was $6.5 \pm 0.4$, essentially the same as the control value. This asymmetry in the malleability of primary dendrites may reflect the fact that the 2 experimental surgeries were performed at different ages. Since the adult number of dendrites is already established by 4 weeks of age (Voyvodic, 1987a), it is perhaps not surprising that reducing target size at this stage leads to a uniformly smaller arborization than normal, rather than to the complete elimination of some primary branches.

To test whether neurons selected by intracellular injection of HRP are representative of the entire population of ganglion cells 
A
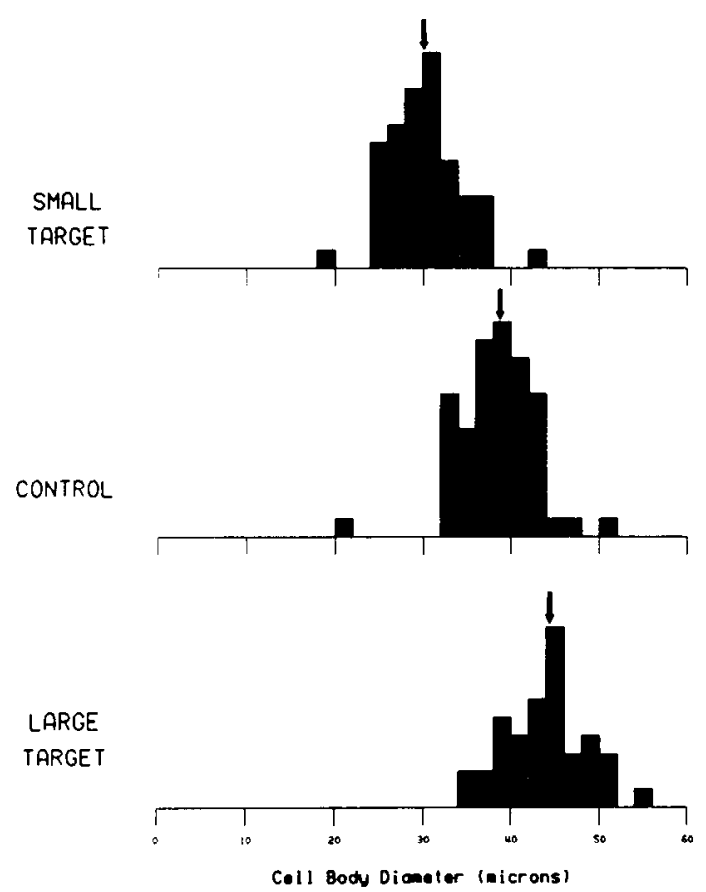

B
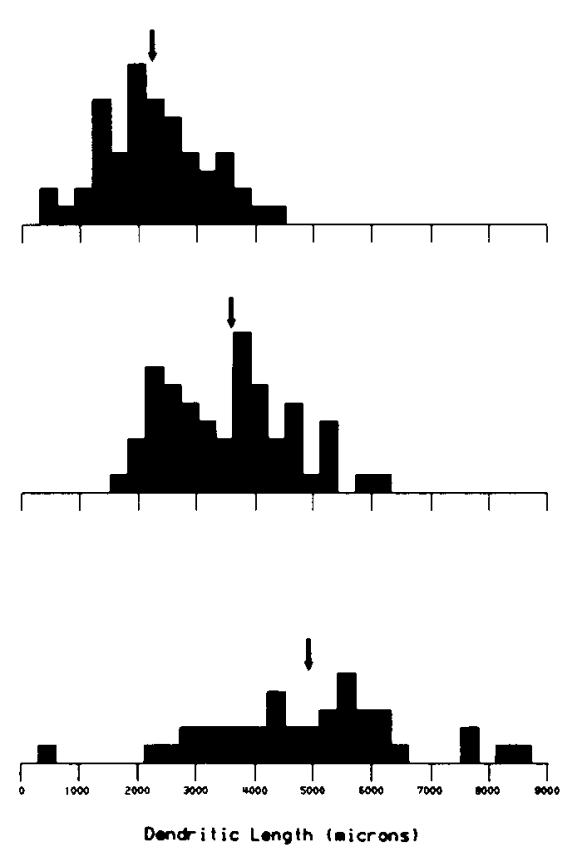

C

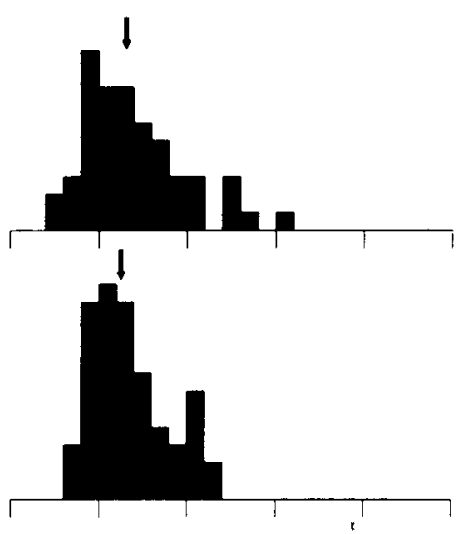

Figure 7. Frequency histograms showing distribution of parameters of neuronal morphology for cells in each experimental group. Animals with ligated submandibular ducts are shown as Small target, and animals in which the submandibular gland was partially denervated are denoted by Large target. $A$, Cell soma diameter; $B$, total dendritic length; and $C$, number of primary dendrites. Arrows indicate mean values.

innervating the submandibular gland, cell soma size was also measured using Di-I as a retrogradely transported label. By this technique, which labels a large population of the ganglion cells projecting to the gland, ligating the salivary duct resulted in a $19 \%$ decrease in soma size compared with controls, while partially denervating the submandibular gland produced a $20 \%$ increase (Table 2). These numbers are in reasonable agreement with the changes in cell soma diameter determined by intracellular staining (see Table 3) and indicate that the neurons injected intracellularly are representative of the affected ganglion cell populations.

To ascertain whether these morphological changes in ganglion cells occurred only in neurons that projected to the experimen- tally modified target, 26 neurons innervating other peripheral targets were also labeled with HRP. Neurons projecting to targets other than the submandibular gland were identified by the absence of retrograde Di-I labeling. The dendritic geometries of non-gland-projecting neurons in animals with ligated salivary ducts $(n=5$; total dendritic length $=1942 \pm 276 \mu \mathrm{m}$ with 5.6 \pm 0.7 primary dendrites) or partially denervated submandibular glands $(n=11$, length $=1883 \pm 269 \mu \mathrm{m}$ with $5.4 \pm 0.9$ primary dendrites) were similar to non-gland-projecting neurons in control animals ( $n=10$, length $=2198 \pm 318 \mu \mathrm{m}$ with 5.8 primary dendrites). Within a single ganglion, neurons containing $\mathrm{Di}-\mathrm{I}$ were all similarly affected by surgical manipulations of the submandibular gland, whereas cells without Di-I all appeared to

Table 2. Effect of relative target size on the dendritic geometry of neurons innervating the submandibular gland

\begin{tabular}{|c|c|c|c|c|}
\hline Parameter & Control & $\begin{array}{l}\text { Ligated } \\
\text { salivary } \\
\text { duct }\end{array}$ & $\begin{array}{l}\text { Partially } \\
\text { denervated } \\
\text { gland }\end{array}$ & $\begin{array}{l}\text { Partially } \\
\text { denervated } \\
\text { gland and } \\
\text { denervated } \\
\text { SCG }\end{array}$ \\
\hline No. of animals & 12 & 9 & 9 & 2 \\
\hline No. of cells & 59 & 53 & 40 & 12 \\
\hline Total dendritic length $(\mu \mathrm{m})$ & $3527 \pm 141$ & $2242^{a} \pm 119$ & $4865^{a} \pm 258$ & $4716^{a} \pm 527$ \\
\hline No. of primary dendrites & $6.3 \pm 0.3$ & $6.5 \pm 0.4$ & $12.9^{a} \pm 0.6$ & $13.7^{a} \pm 1.3$ \\
\hline Cell body diameter $(\mu \mathrm{m})$ & $38.4 \pm 0.6$ & $30.1^{a} \pm 0.6$ & $43.7^{a} \pm 0.7$ & $48.3^{a} \pm 1.6$ \\
\hline
\end{tabular}

Means are given \pm SEM.

"Values significantly different from controls ( $p<0.005$ by Student's $t$ test). 
be unaffected by the surgery (Fig. 8). Effects on neuronal geometry, therefore, are specific to those neurons that innervate the affected target.

\section{Role of preganglionic innervation}

In 2 animals, presynaptic innervation to the ganglion was removed at birth by ligating and cutting the sympathetic trunk at the same time that the relative size of the target was increased by partially denervating the salivary gland. When neuronal morphology was examined in these animals at 4-6 months of age, cell body size, total dendritic length, and the number of primary dendrites had all increased compared with controls, just as in the case of target denervation alone (Table 2). Therefore, the size and shape of the dendritic arborization appear to be controlled by the size of the peripheral target available to each neuron, independent of the presence or absence of preganglionic innervation.

\section{Effects of target size on neuronal morphology are continuously graded}

The surgical procedures used in these experiments produced considerable variability in both neuronal number and gland size. By comparing dendritic geometry to relative target size on an animal-by-animal basis, this variability could be used to examine the sensitivity of neuronal geometry to incremental changes in target size. Accordingly, relative target size was calculated for each experimental animal by dividing the weight of the submandibular gland by the number of ganglion cell axons projecting to the gland in that animal. Measurements of ganglion cell geometry were determined for each animal by averaging the values of all HRP-filled neurons in each ganglion. The changes observed in cell soma size, total dendritic length, and the number of primary dendrites were then plotted as a function of relative target size (Fig. 9).

When the data from all experimental groups - animals with duct ligations, partially denervated glands, preganglionic denervations, and control animals - are combined in this way, it is clear that the primary determinant of all 3 morphological parameters is the relative size of the peripheral target, regardless of the experimental manipulation performed. Furthermore, the effect of relative target size varies in a graded manner. Thus, cell soma size, total dendritic length, and the number of dendrites all increased progressively over the full range of target sizes, although the rate of change in these parameters was less for very small or very large targets. This plateau effect may be related to the fact that the size of the axonal arborizations within the salivary gland does not vary linearly with gland size (see Fig. 5). Overall, however, the size of a ganglion cell's peripheral target is a good predictor of both neuronal size and the geometry of the dendritic arborization.

\section{Effect of peripheral target size on preganglionic innervation}

To test the functional consequences of target-induced changes in dendritic geometry, the number of preganglionic axons making synaptic contacts with ganglion cells innervating the submandibular gland was determined in both control animals and in animals with larger than normal peripheral targets. The results are shown in Table 3 . There was no significant difference between the 2 groups in terms of the average size of excitatory postsynaptic responses, nor in the ratio of subthreshold to superthreshold responses. The segmental distribution of preganglionic inputs for the 2 conditions was also similar. There was,
Table 3. Effect of relative target size on the innervation of superior cervical ganglion cells by preganglionic inputs

\begin{tabular}{|c|c|c|}
\hline Parameter & Control & $\begin{array}{l}\text { Partially } \\
\text { denervated } \\
\text { gland }\end{array}$ \\
\hline No. of animals & 3 & 5 \\
\hline No. of neurons studied & 21 & 23 \\
\hline \multicolumn{3}{|l|}{ Average no. of axons } \\
\hline \multicolumn{3}{|l|}{ Innervating submandibular } \\
\hline $\begin{array}{l}\text { Average EPSP amplitude } \\
(\mathrm{mV})\end{array}$ & $7.7 \pm 0.7$ & $7.4 \pm 0.5$ \\
\hline \multicolumn{3}{|l|}{ Fraction of EPSPs } \\
\hline superthreshold (\%) & 24 & 26 \\
\hline No. of preganglionic inputs & $6.4 \pm 0.5$ & $9.6 \pm 0.7^{a}$ \\
\hline
\end{tabular}

however, a significant increase in the average number of axons contacting ganglion cells that innervated the enlarged targets. Thus, neurons that innervated glands in control animals were contacted by $6.4 \pm 0.5$ inputs on average, whereas neurons innervating relatively larger targets were contacted by $9.6 \pm 0.7$ axons. Therefore, increasing the size of the pcripheral target, which increases dendritic complexity of superior cervical ganglion cells, also produces a corresponding increase in the degree of convergent preganglionic innervation.

\section{Discussion}

This study shows that the morphology of neurons in the superior cervical ganglion is affected by changing the relative size of the postganglionic target. Reducing target size causes dendritic arborizations to be smaller than normal; conversely, increasing relative target size results in a substantial increase in dendritic length and complexity. Altering relative target size also produces parallel changes in the size of the neuronal cell body and the degree of preganglionic convergence. Since the relationship between target size and neuronal form is not affected by removing preganglionic innervation, target regulation of ganglion cell geometry appears to operate independently of neuronal activity or other presynaptic influences.

It follows from these results that axonal targets exert a more pervasive influence over the neurons that innervate them than is generally assumed. It has long been believed that target-derived trophic signals match the size of neuronal populations to the size of their peripheral fields early in normal development (Hamburger and Oppenheim, 1982). The experiments described here indicate that, in at least some parts of the nervous system, neuronal size and dendritic geometry are influenced by relative target size, just as is the case for neuronal number. Therefore, the initial establishment of neuronal number early in life appears to represent only the first step in an ongoing process of feedback control. After the number of neurons is established, ganglion cells continue to adjust to changes in the size and form of their targets by modulating cell body size and the size and complexity of their axonal and dendritic processes (see Purves, 1988, for a general treatment of these ideas).

The experimental manipulations reported here were all carried out in young animals (up to 4 weeks of age); the correlation between dendritic morphology and target size, however, was 
Figure 8. Specificity of target regulation of dendritic geometry. Dendrites of several HRP-labeled neurons have been traced in this camera lucida drawing of a superior cervical ganglion from an animal whose right submandibular gland was partially denervated at birth. The ganglion cells were intracellularly labeled when the rat was 5 months of age. In this tracing, cell positions were shifted slightly for clarity; axons are indicated with dotted lines. Neurons indicated by asterisks were identified as projecting to the right submandibular gland by the presence of the retrograde fluorescent tracer Di-I. The cells without asterisks were not labeled with Di-I and therefore innervated peripheral targets other than the submandibular gland. All cells projecting to the partially denervated target were more complex than normal due to the surgical manipulation, whereas the surgery had no apparent effect on any cells in. nervating other targets.

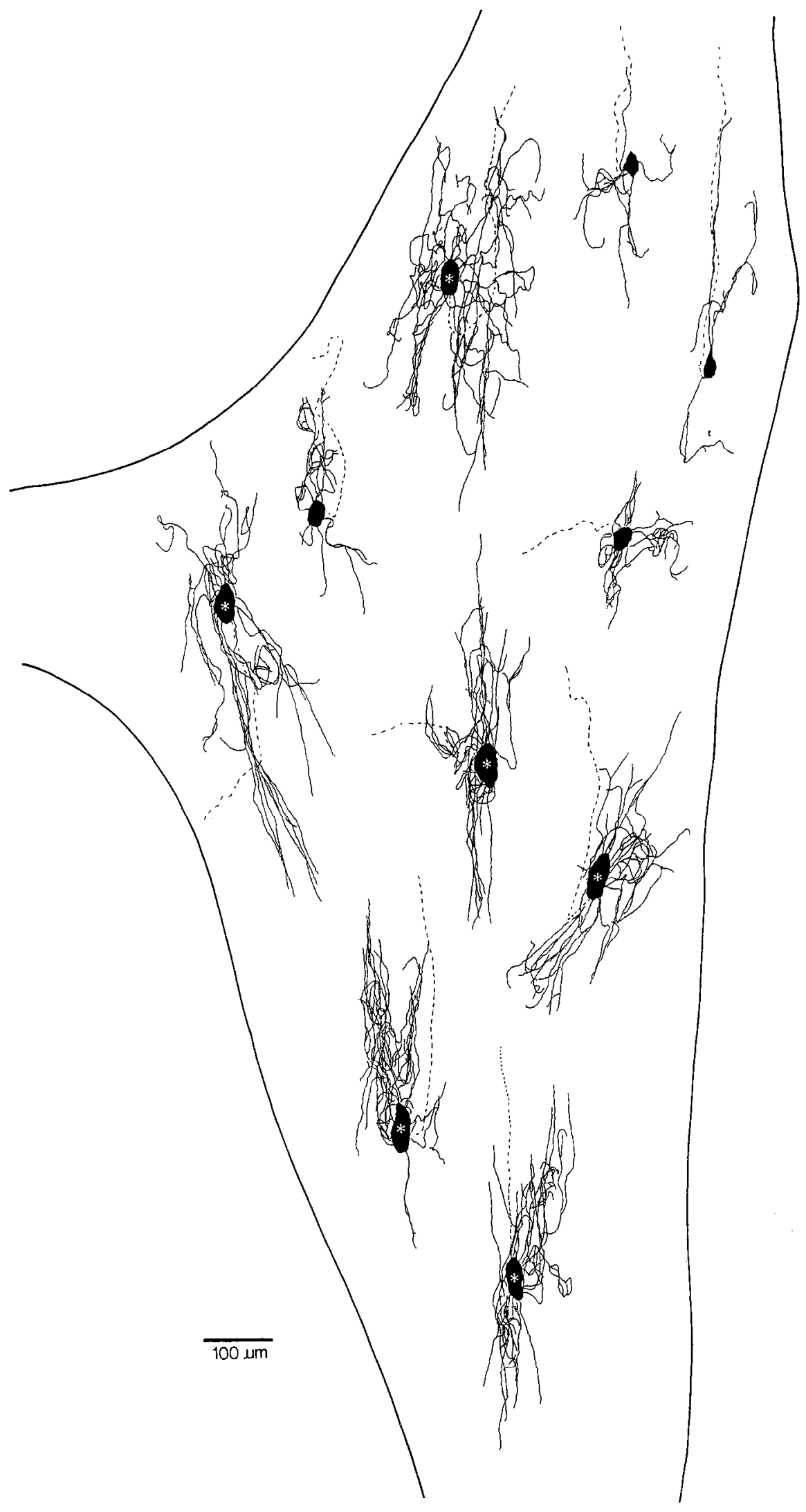

observed months later in adulthood (see Fig. 9). The persistence of this correlation long after the initial surgery suggests that dendrites continue to change with target size throughout life. This inference is further supported by the observation in normal rats that dendritic growth continues in proportion to overall animal growth long after these animals have reached adulthood (at least up to 16 months) (Voyvodic, 1987a). Furthermore, studies of identified neurons in the superior cervical ganglion 
A

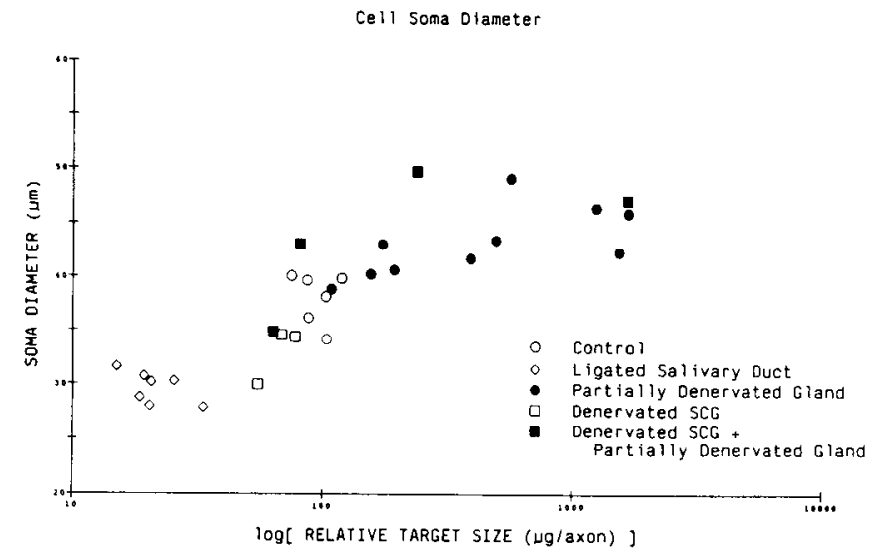

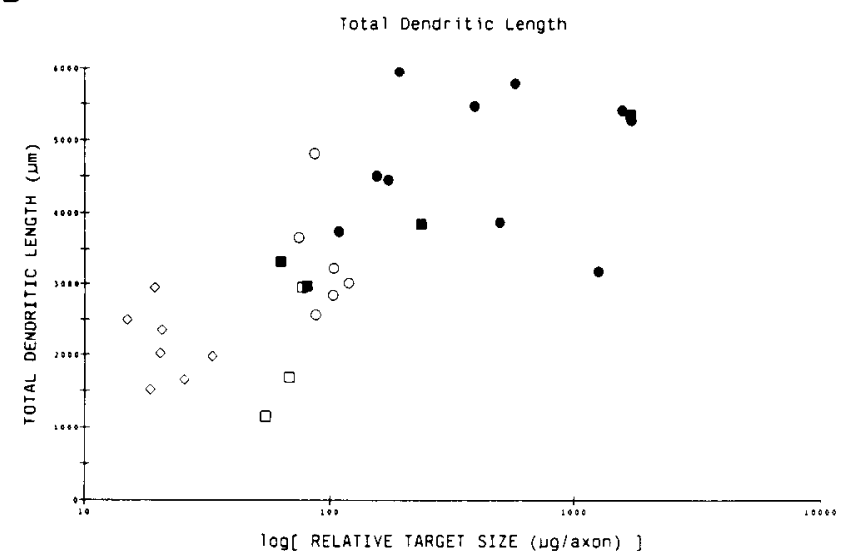

C

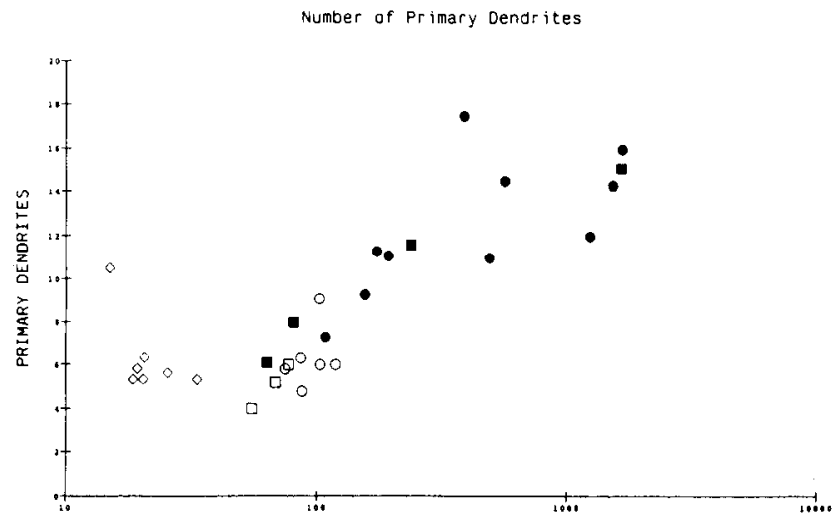

log[ RELATIVE TARGET SIZE (ug/axon) ]

Figure 9. Variations in neuronal morphology as a function of relative target size. In each graph, each data point represents the averaged value for all HRP-labeled neurons in one animal. The symbol legend indicates the surgical procedures performed. Relative target size for each animal was calculated as the mass of the submandibular gland, divided by the number of innervating ganglion cells as determined by counting axons in the sympathetic postganglionic nerve. $A$, Cell soma diameter; $B$, total dendritic length; and $C$, number of primary dendrites.

of mice indicate that, even in maturity, dendrites undergo a continuous process of extension and retraction (Purves et al., 1986b). Finally, when ganglion cells in adult mice are disconnected from their target by cutting the postganglionic nerves, there is an overall regression of the dendritic arborization that reverses when the severed axons reinnervate the periphery (Yawo, 1987). These several lines of evidence indicate that the regulation of ganglion cell dendrites is continuously modulated throughout life by signals arising from the peripheral targets.

Interestingly, the same target-dependent regulatory interactions considered here in the ontogeny of individual animals are also pertinent to phylogeny. Comparisons among species have shown that the complexity of autonomic ganglion cells increases in proportion to increasing animal size among related mammals (Purves and Lichtman, 1985a; Purves et al,, 1986a; Snider, 1987). Variations in size of homologous targets among species could largely explain these observed differences in the geometry of corresponding neurons without recourse to species differences intrinsic to the neurons themselves. In both ontogeny and phylogeny, the same target-dependent regulatory mechanisms may operate to ensure that neuronal morphology is matched to the size of the peripheral targets.

\section{Mechanism of dendritic regulation}

The most likely molecular mechanism to explain the regulation of ganglion cell dendrites by peripheral targets is the uptake and transport of one or more target-derived trophic factors. This suggestion is based on the example of feedback regulation of cell number in the nervous system, in which case it is widely believed that individual neurons compete for acquisition of trophic molecules produced by the target in limited supply (Hamburger and Oppenheim, 1982; Purves and Lichtman, 1985b). The results presented here are all consistent with a trophic explanation of the influence of targets on ganglion cell dendrites and their innervation. Other evidence that supports a trophic explanation of the present observations is the reversible effect of postganglionic axotomy on dendritic geometry (see above). These effccts of axotomy, as well as the results reported here on target size, imply that the maintenance of dendritic geometry depends on the continuous supply of some axonally transported signal. In this view, the size of the dendritic arborization is regulated by the amount of trophic factor acquired from targets, which is in turn proportional to the size of the target innervated. 
In the superior cervical ganglion, the protein nerve growth factor (NGF) is known to be involved in trophic interactions between ganglion cells and their targets and to affect axonal branching (Levi-Montalcini, 1987); this molecule is therefore a good candidate for the signal responsible for the regulation of dendrites. NGF is produced in small amounts in target tissues, including the rat submandibular gland (Korsching and Thoenen, 1983; Shelton and Reichardt, 1984), where it binds to specific receptors on sympathetic nerve terminals and is then actively transported to the superior cervical ganglion by postganglionic axons (reviewed by Thoenen and Barde, 1983). Although the existence of NGF was predicted from its role in supporting ganglion cell survival (Levi-Montalcini, 1987), it has also been shown to affect cell soma diameter (Hendry and Campbell, 1976; Schäfer et al., 1983) and to promote process outgrowth both in vitro (Campenot, 1977, 1982a, b; Chun and Patterson, 1977) and in vivo (Hendry and Campbell, 1976; Schäfer et al., 1983). Most directly, Snider (1988) has recently shown that exogenous NGF given to neonatal rats can significantly enhance dendritic growth as well.

In summary, considerable circumstantial evidence indicates that the retrograde regulation of dendrites described in the present study is mediated, at least in part, by the amount of NGF available to ganglion cell axons within the target.

\section{Regulation of preganglionic innervation by postganglionic targets}

The fact that dendritic complexity in the superior cervical ganglion is influenced by target size implies that feedback signals from the periphery also regulate the pattern of preganglionic innervation a ganglion cell receives. This conclusion is based on 2 different lines of evidence that have related presynaptic innervation to ganglion cell geometry. First, there is a strong correlation in mature animals between the number of preganglionic inputs a neuron receives and its dendritic complexity (Hume and Purves, 1981; Purves and Hume, 1981; Purves and Lichtman, 1985a). Ganglion cells with few primary dendrites are innervated by relatively few preganglionic axons on average, whereas cells with more dendrites are innervated by proportionally more inputs. This correlation implies a regulatory mechanism that matches input number and dendritic complexity. The observation that regulation of dendrites is largely independent of preganglionic innervation (Voyvodic, 1987a, and the present results) suggests that the correlation between dendritic number and the number of convergent inputs is determined by the geometry of the postsynaptic cell (see also Hume and Purves, 1981). The fact that ganglion cells projecting to experimentally enlarged targets have an unusually large number of primary dendrites and also receive an unusually large number of preganglionic inputs confirms this inference.

In addition to modulating the number of inputs that converge onto a ganglion cell, postsynaptic geometry is also likely to influence the total number and distribution of individual presynaptic contacts. This suggestion has been borne out in frog parasympathetic ganglia, where the number of synaptic boutons a ganglion cell receives is directly proportional to ganglion cell soma size (Sargent, 1983). Cell body size in this frog ganglion has, in turn, been shown to be regulated by the size of the peripheral target (Heathcote and Sargent, 1987). In the rat superior cervical ganglion, where most synapses are made on dendrites (Forehand, 1985), the fact that dendritic length changes continuously throughout life suggests that synapses made on those dendrites must also be continuously changing. Therefore, regulation of dendritic geometry by peripheral target size presumably provides an ongoing mechanism for modulating the total number of synapses a ganglion cell receives.

The functional consequences of changing a cell's dendritic geometry, and therefore the number or distribution of presynaptic contacts, is not well understood. In autonomic ganglia, it has been suggested that increased convergence of preganglionic inputs might act to amplify efferent signals through the ganglion by increasing the overall rate of ganglion cell activity (Purves et al., 1986a). It is known, for example, that as the number of inputs a ganglion cell receives increases, the normal frequency of postsynaptic activity also increases (Johnson and Purves, 1983; Ivanov and Purves, 1989). In accord with these findings, measuring the level of ongoing synaptic activity in control neurons and in neurons innervating relatively larger than normal peripheral targets indicates that experimentally increased dendritic complexity causes a significant increase in the rate of ongoing synaptic activity in the affected ganglion cells (Voyvodic and Ivanov, 1988). These observations are consistent with the view that regulation of dendritic geometry by peripheral targets helps to match the functional properties of an efferent pathway to the requirements of the target it innervates.

\section{Regulation of dendrites in other regions of the nervous system}

Whether retrograde trophic regulation of neuronal geometry is a general phenomenon in the nervous system remains an open question. Certainly target size is not the only factor determining dendritic form. To some degree, dendritic geometry reflects intrinsic properties of different classes of neurons since type-specific neuronal arborizations can be expressed in vitro (Scott et al., 1969; Dichter, 1978; Banker and Cowan, 1979; Wakshull et al., 1979; Kriegstein and Dichter, 1983). Moreover, in many areas of the CNS dendritic form is clearly influenced by presynaptic innervation (reviewed by Coleman and Buell, 1985). In some sensory nuclei, for instance, removing innervation or simply blocking presynaptic activity can prevent dendritic growth or cause a retraction of the dendritic arborization (Larsell, 1931; Levi-Montalcini, 1949; Wiesel and Hubel, 1963; Benes et al., 1977; Harris and Woolsey, 1981; Deitch and Rubel, 1984); conversely, experimentally induced hyperinnervation can in some cases result in the formation of supernumerary dendrites (Goodman and Model, 1988). However, in other regions of the CNS the importance of presynaptic influences in development is less apparent. For example, the dendritic arborizations of primary motor neurons of the brain stem and spinal cord are not dramatically altered by removal of their major descending inputs (Standler and Bernstein, 1984), although dendrites retract following transection of motor axons in the periphery (Grant, 1965, 1968; Sumner and Watson, 1971; Standler and Bernstein, 1982). These neurons, which can be regarded as analogs of the visceral motor neurons of the superior cervical ganglion, may also be largely regulated by their target connections. In general, primary sensory and motor neurons may represent 2 extremes in which dendrites are regulated by either presynaptic or target connections. The dendrites of most neurons, however, are likely to be influenced by both of these epigenetic regulatory strategies.

In conclusion, the dendritic geometry and innervation of superior cervical ganglion cells is modulated by the size of their peripheral targets. Evidently, retrograde trophic signals taken 
up by axons within the target influence the size and shape of dendritic arborizations within the ganglion. This feedback mechanism enables ganglion cells to continuously adjust their functional characteristics to the changing requirements of their peripheral targets.

\section{References}

Banker, G. A., and W. M. Cowan (1979) Further observations on hippocampal neurons in dispersed cell culture. J. Comp. Neurol. 187: 167-191.

Benes, F. M., T. N. Parks, and E. W. Rubel (1977) Rapid dendritic atrophy following deafferentation: An EM morphometric analysis. Brain Res. 122: 1-13.

Betz, W. J., J. H. Caldwell, and R. R. Ribchester (1980) The effects of partial denervation at birth on the development of muscle fibres and motor units in rat lumbrical muscle. J. Physiol. (Lond.) 303: 265279.

Brown, M. C., J. K. S. Jansen, and D. Van Essen (1976) Polyneuronal innervation of skeletal muscle in new-born rats and its elimination during maturation. J. Physiol. (Lond.) 261: 387-422.

Campenot, R. B. (1977) Local control of neurite development by nerve growth factor. Proc. Natl. Acad. Sci. USA 74: 4516-4519.

Campenot, R. B. (1982a) Development of sympathetic neurons in compartmentalized cultures. I. Local control of neurite growth by nerve growth factor. Dev. Biol. 93: 1-12.

Campenot, R. B. (1982b) Development of sympathetic neurons in compartmentalized cultures. II. Local control of neurite survival by nerve growth factor. Dev. Biol. 93: 13-21.

Chun, L. L. Y., and P. H. Patterson (1977) Role of nerve growth factor in the development of rat sympathetic neurons in vitro. I. Survival, growth, and differentiation of catecholamine production. J. Cell Biol. 75: 694-704.

Coleman, P. D., and S. J. Buell (1985) Regulation of dendritic extent in developing and aging brain. In Synaptic Plasticity, C. W. Cotman, ed., pp. 311-333, Guilford, New York.

Deitch, J. S., and E. W. Rubel (1984) Afferent influences on brain stem auditory nuclei of the chicken: Time course and specificity of dendritic atrophy following deafferentation. J. Comp. Neurol. 229: 66-79.

Dichter, M. A. (1978) Rat cortical neurons in cell culture: Culture methods, cell morphology, electrophysiology, and synapse formation. Brain Res. 149: 279-293.

Fladby, T., and J. K. S. Jansen (1987) Postnatal loss of synaptic terminals in the partially denervated mouse soleus muscle. Acta Physiol. Scand. 129: 239-246.

Forehand, C. J. (1985) Density of somatic innervation on mammalian autonomic ganglion cells is inversely related to dendritic complexity and preganglionic convergence. J. Neurosci. 5: 3403-3408.

Goodman, L. A., and P. G. Model (1988) Superinnervation enhances the dendritic branching pattern of the Mauthner cell in the developing axolotl. J. Neurosci. 8: 776-791.

Grant, G. (1965) Degenerative changes in dendrites following axonal transection. Experientia 21:1-4.

Grant, G. (1968) Silver impregnation of degenerating dendrites, cells, and axons central to axonal transection. II. A Nauta study on spinal motor neurons in kittens. Exp. Brain Res. 6: 284-293.

Hamburger, V., and R. W. Oppenheim (1982) Naturally occurring neuronal death in vertebrates. Neurosci. Comment. 1: 39-55.

Hanker, J. S., P. E. Yates, C. B. Metz, and A. Rustioni (1977) A new specific sensitive and non-carcinogenic reagent for the demonstration of horseradish peroxidase. Histochem. J. 9: 789.

Harris, R. M., and T. A. Woolsey (1981) Dendritic plasticity in mouse barrel cortex following postnatal vibrissa follicle damage. J. Comp. Neurol. 196: 357-376.

Heathcote, R. D., and P. B. Sargent (1987) Growth and morphogenesis of an autonomic ganglion. 1: Matching neurons with target. J. Neurosci. 7: 2493-2501.

Hendry, I. A., and J. Campbell (1976) Morphometric analysis of the rat superior cervical ganglion after axotomy and nerve growth factor treatment. J. Neurocytol. 5: 351-360.

Honig, M. G., and R. I. Hume (1986) Fluorescent carbocyanine dyes allow living neurons of identified origin to be studied in long-term culture. J. Cell Biol. 103: 171-187.
Hume, R. I., and D. Purves (1981) Geometry of neonatal neurones and the regulation of synapse elimination. Nature $293: 469-471$.

Ivanov, A., and D. Purves (1989) Ongoing electrical activity of superior cervical ganglion cells in mammals of different size. J. Comp. Neurol. (in press).

Johnson, D. A., and D. Purves (1981) Postnatal reduction in neural unit size in the rabbit ciliary ganglion. J. Physiol. (Lond.) 318: 143159.

Johnson, D. A., and D. Purves (1983) Tonic and reflex synaptic activity recorded in ciliary ganglion cells of anesthetized rabbits. J. Physiol. (Lond.) 339: 599-613.

Korsching, S., and H. Thoenen (1983) Nerve growth factor in sympathetic ganglia and corresponding target organs of the rat: Correlation with density of sympathetic innervation. Proc. Natl. Acad. Sci. USA 80: 3513-3516.

Kriegstein, A. R., and M. A. Dichter (1983) Morphological classification of rat cortical neurons in cell culture. J. Neurosci. 3: 16341647.

Larsell, O. (1931) The effect of experimental excision of one eye on the development of the optic lobe and opticus layer in larvae of the tree frog (Hyla regilla). II. The effect on cell size and differentiation of cell processes. J. Exp. Zool. 58: 1-20.

Lev-Tov, A., J. P. Miller, R. E. Burke, and W. Rall (1983) Factors that control amplitude of EPSPs in dendritic neurons. J. Neurophysiol. $50: 399-412$.

Levi-Montalcini, R. (1949) The development of the acoustico-vestibular centers in the chick embryo in the absence of afferent root fiber and of descending fiber tracts. J. Comp. Neurol. 91: 209-241.

Levi-Montalcini, R. (1987) The nerve growth factor: Thirty-five years later. EMBO J. 6: 1145-1154.

McLachlan, E. M. (1974) The formation of synapses in mammalian sympathetic ganglia re-innervated with preganglionic or somatic nerves. J. Physiol. (Lond.) 237: 217-242.

Njå, A., and D. Purves (1977) Specific innervation of guinea-pig superior cervical ganglion cells by preganglionic fibres arising from different levels of the spinal cord. J. Physiol. (Lond.) 264: 565-583.

Oppenheim, R. W. (1981) Neuronal cell death and some related regressive phenomena during neurogenesis: A selective historical review and a progress report. In Studies in Developmental Neurobiology. Essays in Honor of Viktor Hamburger, W. M. Cowan, ed., pp. 74 133, Oxford U. P., New York.

Purves, D. (1988) Body and Brain: A Trophic Theory of Neural Connections, Harvard U. P., Cambridge, MA.

Purves, D., and R. I. Hume (1981) The relation of postsynaptic geometry to the number of presynaptic axons that innervate autonomic ganglion cells. J. Neurosci. 1: 441-452.

Purves, D., and J. W. Lichtman (1985a) Geometrical differences among homologous neurons in mammals. Science 228: 298-302.

Purves, D., and J. W. Lichtman (1985b) Principles of Neural Development, Sinauer, Sunderland, MA.

Purves, D., E. Rubin, W. D. Snider, and J. Lichtman (1986a) Relation of animal size to convergence, divergence, and neuronal number in peripheral sympathetic pathways. J. Neurosci. $6: 158-163$.

Purves, D., R. D. Hadlcy, and J. T. Voyvodic (1986b) Dynamic changes in the dendritic geometry of individual neurons visualized over periods of up to three months in the superior cervical ganglion of living mice. J. Neurosci. 6: 1051-1060.

Rall, W. (1977) Core conductor theory and cable properties of neurons. In Handbook of Physiology, Sect. 1, The Nervous System, Vol. 1, Cellular Biology of Neurons, E. R. Kandel, ed., pp. 39-97, American Physiol. Soc., Bethesda, MD.

Sargent, P. B. (1983) The number of synaptic boutons terminating on Xenopus cardiac ganglion cells is directly correlated with cell size. J. Physiol. (Lond.) 343: 85-104.

Schäfer, T., M. E. Schwab, and H. Thoenen (1983) Increased formation of preganglionic synapses and axons due to retrograde transsynaptic action of nerve growth factor in the rat sympathetic nervous system. J. Neurosci. 3: 1501-1510.

Scott, B. E., V. E. Engelbert, and K. C. Fisher (1969) Morphological and electrophysiological characteristics of dissociated chick embryonic spinal ganglion cells in culture. Exp. Neurol. 23: 230-248.

Shelton, D. L., and L. F. Reichardt (1984) Expression of the betanerve growth factor gene correlates with the density of sympathetic innervation in effector organs. Proc. Natl. Acad. Sci. USA 81: $7951-$ 7955. 
Smolen, A. J., and P. Beaston-Wimmer (1986) Dendritic development in the rat superior cervical ganglion. Dev. Brain Res. 29: 245-252.

Snider, W. D. (1987) The dendritic complexity and innervation of submandibular neurons in five species of mammals. J. Neurosci. 7: $1760-1768$.

Snider, W. D. (1988) Nerve growth factor enhances dendritic arborization of sympathetic ganglion cells in developing mammals. J. Neurosci. 8: 2628-2634.

Standler, N. A., and J. J. Bernstein (1982) Degeneration and regeneration of motoneuron dendrites after ventral root crush: Computer reconstruction of dendritic fields. Exp. Neurol. 75: 600-615.

Standler, N. A., and J. J. Bernstein (1984) Dendritic alteration of spinal motoneurons after ablation of somatomotor cortex. Exp. Neurol. 83: 264-273.

Sumner, B. E. H., and W. E. Watson (1971) Retraction and expansion of the dendritic tree of motor neurones of adult rats induced in vivo. Nature 233: 273-275.

Tamarin, A. (1966) Secretory cell alterations with submaxillary gland duct ligation. In Secretory Mechanisms in Salivary Glands, L. H. Schneyer and C. A. Schneyer, eds., pp. 220-237, Academic, New York.

Tervo, K., T. Tervo, and A. Palkema (1978) Pre- and postnatal development of catecholamine-containing and cholinesterase-positive nerves of the rat cornea and iris. Anat. Embryol. 154: 253-265.

Thoenen, H., and Y. A. Barde (1980) Physiology of nerve growth factor. Physiol. Rev. 60: 1284-1335.

Thompson, W., and J. K. S. Jansen (1977) The extent of sprouting of remaining motor units in partly denervated immature and adult rat soleus muscle. Neuroscience 2: 523-535.
Voyvodic, J. T. (1986) A general purpose image processing language (IMAGR) facilitates visualizing neuronal structures in fixed tissue and in vivo. Soc. Neurosci. Abstr. 12: 390.

Voyvodic, J. T. (1987a) Development and regulation of dendrites in the rat superior cervical ganglion. J. Neurosci. 7: 904-912.

Voyvodic, J. T. (1987b) Dendritic geometry of sympathetic ganglion cells is regulated by postganglionic target size. Soc. Neurosci. Abstr. 13: 574 .

Voyvodic, J. T., and A. Ivanov (1988) Influence of peripheral target size on normal patterns of synaptic activity of rat superior cervical ganglion cells. Soc. Neurosci. Abstr. 14: 1208.

Wakshull, E., M. I. Johnson, and H. Burton (1979) Postnatal rat sympathetic neurons in culture. I. A comparison with embryonic neurons. J. Neurophysiol. 42: 1410-1425.

Wiesel, T. N., and D. H. Hubel (1963) Effects of visual deprivation on morphology and physiology of cells in the cat's lateral geniculate body. J. Neurophysiol. 26: 978-993.

Womble, M. D., and S. Roper (1987) Retrograde effects of target atrophy on submandibular ganglion neurons. J. Neurophysiol. 58: 276-287.

Wright, L. L., T. J. Cunningham, and A. J. Smolen (1983) Developmental neuron death in the rat superior cervical sympathetic ganglion: Cell counts and ultrastructure. J. Neurocytol. 12: 727-738.

Yawo, H. (1987) Changes in the dendritic geometry of mouse superior cervical ganglion cells following postganglionic axotomy. J. Neurosci. 7: 3703-3711. 